\title{
Erratum für das Heft 3/2012
}

Aufgrund eines technischen Fehlers wurde eine Fußnote des Beitrags "Truth and Lies about Gregor Samsa. The Logic Underlying the Two Conflicting Versions in Kafka's Die Verwandlung "von Fernando Bermejo-Rubio im Heft 3/ 2012 unvollständig abgedruckt.

Die Fußnote 119 auf Seite 444 lautet vollständig:

${ }^{119}$ This aspect is easier to understand when one realises that Gregor Samsa is, as has so often been stated, to a certain extent a self-critical "fictionalisation " of Franz Kafka, who gave expression to a delicate personal situation (the recrudescence of the exigencies of his family, aimed at persuading him to inspect the asbestos factory of his brother-in-law Karl Hermann). Die Verwandlung is a kind of caveat, through which Kafka observes his possible destiny in case of yielding to his family's (including now Ottla's) demands. In this sense, Gregor represents an alter ego in which Kafka has embodied his own weakness and feelings of guilt. For the biographical context, see Hartmut Binder, "Kafka und seine Schwester Ottla. Zur Biographie der Familiensituation des Dichters unter besonderer Berücksichtigung der Erzählungen 'Die Verwandlung، und ,Der Bau“", Jahrbuch der Deutschen Schillergesellschaft 12 (1968), 403-456. 21st November 1912, four days after having begun to write Die Verwandlung, Kafka avows to Felice Bauer: "Ich habe die Eltern immer als Verfolger gefühlt " (Franz Kafka, Briefe an Felice, eds. Erich Heller, Jürgen Born, Frankfurt a.M. 1976, 112). 